\title{
The painter Meri Genetz and the endless quest for spiritual wisdom
}

\author{
DOI: https://doi.org/10.30664/ar.100545
}

(c) (9ttribution 4.0 International (CC BY 4.0)

M eri Genetz (1885-1943) was a Finnish painter, esotericist, and a spiritual seeker. Around 1925, she began truly dedicating herself to spiritual seeking and started to make notes of her studies in black notebooks. This article will go through four of those notebooks which today offer a vivid picture of Genetz's seeking between the years 1925 and 1943. In the beginning, Genetz acquainted herself with Gnosticism, Theosophy, and Kabbalah, as well as the works of Christian mystics, such as Emanuel Swedenborg and Jakob Böhme, the writings of, for example, Paracelsus, and texts attributed to the mythic figure Hermes Trismegistus. Gradually Genetz started to outline her own views, ideas, and theories regarding higher truth and spiritual wisdom. In the beginning of the 1930s her main quest came to be to find her 'other half' and become whole. She started attending Spiritualist séances, where she would ask about her other half and discuss the state of her soul, the souls of others, her art and marriage, and the books she had read. In time, Genetz's quest for true wisdom and selffulfilment became more and more restless and impatient. When she died in 1943, she was still seeking.

Meri Genetz (born in 1885) was a Finnish painter and a very diligent spiritual seeker. Today, her seeking offers a rare opportunity to view the spirituality of the Finnish cultural elite of the early twentieth century. This was a time when the intellectual circles were deeply interested in the esotericism. Genetz's life offers valuable information for the study of esotericism, since she took abundant notes on her occult interests the books she read, her dreams, visions and thoughts, and the conversations that took place, for example, in Spiritualist séances.

\section{Meri Genetz}

Meri Genetz was born in 1885 as an only child to a family whose father Atle Genetz worked as a factory owner in the wood-processing industry. Meri's mother, Leila Genetz (née Toppelius), came from a renowned intellectual family (Ryynänen 2019: 11-13, 17-18, 65, 68).

Meri Genetz studied art at the Drawing School of the Finnish Art Society (today's Academy of Fine Arts) in 1902-4. In 1907, she married an engineer, Georg Ignatius, and moved to Russia. There the family grew by two children, which meant Genetz had to give up painting (Ryynänen 2019: 39-94). She resumed her art in 1919, when she moved to Paris - both in order to study art and to get a divorce. Her children stayed in Finland. In Paris, Genetz met her second husband, the Finnish artist Carl Nyman Wargh ${ }^{1}$ (1895-1937). In the

1 Carl's original family name was Nyman. He changed it to Wargh in 1933. To distinguish him from his nephew, who was also named 


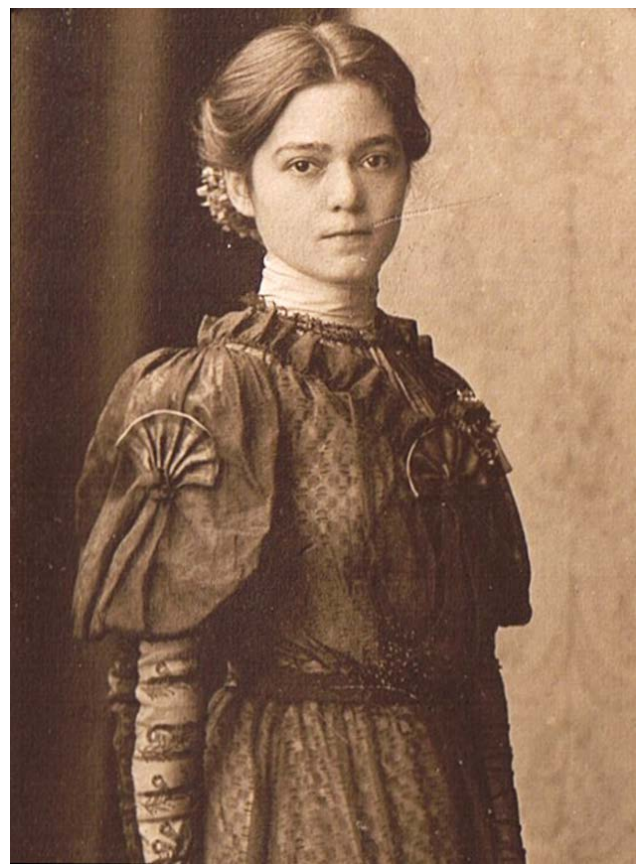

Meri Genetz in the beginning of the twentieth century. Private collection.

1920s, the couple lived mostly in Finland, but also spent long periods of time in France, mainly in Cagnes-sur-Mer by the Mediterranean Sea (ibid. pp. 130-235).

Genetz and Wargh's friends included many notable contemporary Finnish artists. In France with them were the artist couples Matti and Lyyli Björklund (later Visanti), Eemu Myntti and Eva Bremer, Inni Siegberg and Ragnar Ekelund, as well as the artists Eero Nelimarkka, Uno Alanco (later Uuno Alanko), and Ilmari Vuori with his wife Kerttu Vuori. In Finland, the couple had close ties with the sculptor Wäinö Aaltonen, actor Jussi Snellman, writer R. R. Eklund, and artist William

Carl Wargh and was a known Finnish painter, Meri's husband is usually referred to as Carl Nyman Wargh. For convenience, I will here use the name Wargh throughout the text.
Lönnberg (Konttinen 2010: 82, 83; Ryynänen 2019: 141-50,181, 194, 215-20, 227, 290; Tirranen s.d.)

Genetz and Wargh were both modernists, but very different in style. Meri was known of her strong colours and a fast, firm way of working on the canvas. Wargh, on the other hand, painted with great precision and concentration, and his paintings often have a distinct, contemplative atmosphere. Genetz's mother made an observation about the difference between the two, claiming that in the time it took Wargh to make one painting, Gentz made ten (André Lhote and Suomi 1982: 15-16; Holm and Wargh 1995; Konttinen 2010: 87-8; Ryynänen 2019: 155; Tirranen 1950: 440-1; Tirranen s.d.).

In the mid 1930s, Genetz was among the most prominent of contemporary Finnish painters. Her work was regularly accepted into the annual exhibitions of the Artists' Association of Finland and received a favourable reception in the Finnish press. Her paintings were also included in two international exhibitions of Finnish art. In the latter half of 1930s, however, Genetz faced several deep crises in her personal life: Her marriage with Wargh was in ruins; both Genetz and Wargh suffered from mental problems, and in 1937, Wargh committed suicide. Then in 1940, Genetz lost her son in the war (Konttinen 2010: 89-90; Ryynänen 2019: 232-63).

After Wargh's death, Genetz became quite isolated. Most of her friends were people she had found to pose for her from bars and on the streets. Judging by her notes, together with the letters her friends sent to her and other acquaintances, most of the members of her intimate circle suffered from mental instability and alcohol problems. Genetz continued to paint, and her work was still chosen for exhibitions, but it never received the same attention as 
before. After she died of carbon monoxide poisoning in April 1943, she was quite readily forgotten (Konttinen 2010: 73, 90; Ryynänen 2019: 263, 272-4, 289, 303-4; Sonck 1980; Tirranen 1950: 436-7).

Dozens of Genetz's paintings were found in her cellar ten years after her death. They were in poor condition, and many of them have subsequently been restored. The work was presented to the public in a large exhibition in 1980 . It raised considerable interest, but after the exhibition Genetz was forgotten again (Ahlman 1980; Konttinen 2010: 91; Sonck 1995: 204-5). In 2019, Keski-Suomen museo presented Genetz's art in a retrospective exhibition. I was at the opening as a journalist. Ten years later, I published a book about Genetz's life, art, and spiritual seeking. Apart from that book only one article and one book chapter have been published about Genetz and Wargh (Konttinen 2010; Tirranen 1950). There are, however, no biographical articles about Genetz alone.

\section{Meri as a spiritual seeker}

Genetz was probably already familiar with esotericism as a child. At the end of the nineteenth century, her mother's father, Gustaf Toppelius (1825-1906), had written a book about paranormal phenomena including mesmerism and clairvoyance. Esotericism was also a subject of wide interest in Finnish intellectual circles at the time. In early adulthood, Genetz had several friends who were Theosophists and astrologists (Klinge 2006: 544-50; Ryynänen 2019: 101-13, 170-1; Toppelius 1891).

In autumn 1925, Genetz's interest in the occult took on a more systematic form. She started making notes on the books she had read in a black, wax-covered notebook. Later, other similar notebooks followed. The notes are in Swedish or German if the source Meri is quoting is using Swedish or
German. Her own thoughts and ideas Meri wrote in Finnish (Notebooks 1-4).

Today, Meri's notebooks provide us with a vivid picture of Genetz's path as a spiritual seeker. However, Genetz only dated her notes occasionally, and it seems that she filled some of the notebooks simultaneously, so that exact time points or a clear sequence of events aren't always possible. It is, nevertheless, possible to give a rough outline of how the stages in Genetz's seekership followed each other through time (Notebooks 1-4).

Nina Kokkinen (2019a: 27-9, 2019b: $52-3$, in this volume) has described how artists as seekers were selective in using material from different religious and cultural sources. They would not accept any doctrine as a whole, but combined pieces from different sources to build a spiritual ensemble most suitable for them. Personal experience and the person's own spirituality were the highest authorities for choosing what was right or true.

This description captures perfectly Genetz's approach to spirituality. She would never accept any truths from anyone else; in fact, both her correspondence and interviews made with her friends provide an image of someone who believes herself to be the best judge of what is true or right (Genetz, letters 1903-43; Tirranen s.d.). Genetz weighed the teachings of different religions, ideologies, and doctrines according to her own interest. Her seeking was extremely intense and pervasive: after she had truly begun her studies of the occult, nothing would ever surpass them in importance (Notebooks 1-4; Ryynänen 2019).

\section{Gathering sources}

In autumn 1925, Genetz was devouring the books of the Austrian author Gustav Meyrink (1868-1932). Genetz was deeply 
impressed by Meyrink's Das grüne Gesicht (1916, The Green Face). In its pages, Genetz has drawn vertical lines, exclamation marks and underlining to highlight passages which address the idea that most people walk through their life dreaming, yet thinking they are awake. According to Meyrink, the most important thing to do is to realise one is dreaming. From there would begin the process of awakening (Meyrink 1916; Ryynänen 2019: 175).

Quite clearly, Genetz had decided to wake up. Her first notebook begins:

\section{Aug. 1925}

... Hebrews 12.

Ye have not yet resisted unto blood, striving against sin. - The Lord scourgeth every son whom he receiveth. - Lift up the hands which hang down, and the feeble knees. - Looking diligently lest any root of bitterness springing up trouble you - Ye are not come unto the mount that might be touched, and that burned with fire, nor unto blackness, and darkness, and tempest, and the sound of a trumpet, and the voice of words. (Notebook 1$)^{2}$

This quote from the Bible gives a strong foretaste of what was to come: Genetz would not make this easy on herself. She would go unto the mount, walk into the darkness, and endure anything. She would continuously strive to develop and progress. She would ask her books and later the spirits, where to seek next, what to do next, what to try next (Notebooks 1-4; Ryynänen 2019).

2 Original text in Swedish. The translation has been made using Hebrews 12:4-19 (King James Bible Online). All Genetz's notebook excerpts have been translated by the author of this article.
Genetz began her studies with Gnosticism (Notebook 1). The term has been used to describe certain movements of secondand third-century Hellenistic culture. Two ideas were central to most of the movements: firstly that our world, together with the planets, skies, and angels, has not been created by a supreme, transcendent God, but by a demiurge. In an essential text of Gnostic mythology, the Apocryphon of John, the demiurge is called Jaldabaoth. $\mathrm{He}$, unlike the supreme God, is not perfect; quite the contrary, he is stupid and incompetent. The second central idea is that we all have some essence of true deity from the supreme God inside us, but we are not aware of it. According to Gnosticism, we must be awakened from our ignorance to understand our divine origin (van den Broek 2006a: 404-10).

Genetz listed 'the gnostic sources in the Bible': ' 5 books of Moses, psalms of David, psalms of Solomon, Book of Lamentations, Book of Daniel, Book of Wisdom, Ecclesiastes, Gospel of John, Revelation' A little later comes a list of the seven heavens within each other' and their rulers. ${ }^{3}$

\section{1 ruler Ialdabaoth}

his prophets are Moses, Joshua, Amos \& Habakkuk

$\underline{2 \text { Iao }}$

his prophets are Samuel, Nathan, Jonah, Micah

3 Sabaoth prophets: Elijah, Joel, Zechariah

3 Some editing has been done to Genetz's notes in order to enhance their legibility, e.g. abbreviations have been substituted with whole words. Where there are underlinings, they have been done by Genetz. 
4 Adoneus's prophets: Isaiah, Ezekiel, Jeremiah, Daniel

\section{Eloeus' prophets: Tobit, Haggai}

\section{Horeus' prophets: Micah, Nahum}

z Astaphaeus' prophets: Ezra, Zephaniah (Notebook 1$)^{4}$

At the same time, concerning Gnosticism, Genetz was acquainting herself with the texts of the German mystic Jakob Böhme (1575-1624). One of the texts was Of Regeneration:

A True Christian, who is born anew of the Spirit of Christ, is in the Simplicity of Christ, and hath no Strife or Contention with any Man about Religion. He hath Strife enough in himself, with his own Beastial evil Flesh and Blood. He continually thinketh himself a great Sinner, and is afraid of God. (Notebook 1) ${ }^{5}$

Shortly after quoting Böhme on avoiding strife and contention, Genetz wrote: '2 Sept. An overall bad day. Talked too much' (Notebook 1). The virtues of holding one's tongue had already become familiar to her ten years earlier when she was deeply impressed by Maurice Maeterlinck's book The Treasure of the Humble (Genetz, letter 20.2.1917). In it, Maeterlinck (1905: 4-5) writes: 'Speech is of Time, silence is of Eternity ... It is idle to think that, by means of words, any real communication can ever pass from one man to another.'

4 Original text in Swedish. The list has been transliterated with the help of Irenaeus s.d.

5 Original text in Swedish. The translation has been made using Böhme 2009.
In the beginning of 1930s, Genetz still wrote in her pocket notebook and calendar: 'That I could set a lock on my mouth and press an efficient seal on my lips so that I fall not by them and my tongue destroy me not' (Calendar 1932; Small notebook). ${ }^{6}$ This was probably not easy for her. Judging by her conversations and the way her friends described her, she was a fast thinker, a witty, even acerbic, a conversationalist, and keen on speaking her mind (Genetz, letters 1903-43; Ryynänen 2019: 53, 179; Tirranen s.d.).

A long section from the first notebook is given to Jakob Böhme's views on the four humours - the sanguine, phlegmatic, choleric, and melancholic temperaments - or 'the four complexions', as Böhme called them (Behmen s.d.). Genetz took notes on how the devil uses different tactics with different temperament types when seducing people to sin. Possibly she saw herself to be a melancholic, since she wrote one third of a page on each of the other types, but six pages on the melancholic type. According to Böhme and Meri's notes, the devil takes advantage of the melancholic's gloomy spirit and their fear of God's wrath, and persuades them to think they have no hope of the mercy of God. Böhme's advice for them is to not speculate on God's anger, to seek the familiar company of others, and to avoid drunkenness (Behmen s.d.: 38-9; Notebook 1).

A little later Genetz was reading Böhme's book Aurora oder Morgenröte im Aufgang (manuscript was made in 1612) and took notes on the seven principal qualities of the divine power (Notebook 1). Böhme (s.d.) explained how they are reflected on earth:

6 Original text in Swedish. The quotation is reminiscent of Book of Sirach 22:27, but does not follow it word for word. 


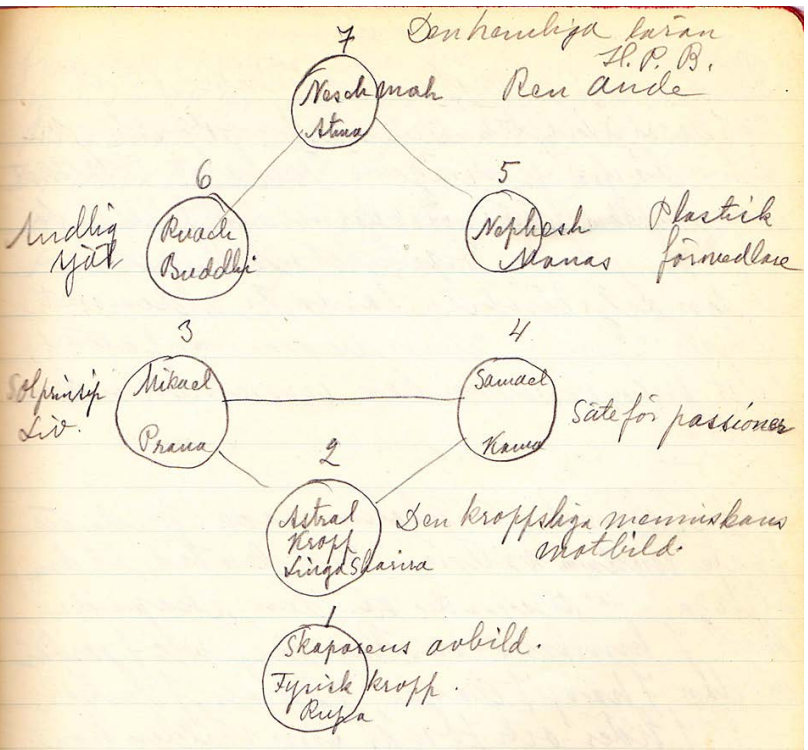

Page from Notebook 1. Private collection.

for example, every flower in the meadow is coloured and named according to the quality it receives. Genetz wrote:

Some are of the quality of the water, and those are light, like the holy heaven; and when the light shineth on them, then they look like to a crystalline sea.

Some are strongest in the bitter quality, and they are like a green precious stone ... and when the light shineth on them, then they shine and appear as a greenish red... (Notebook 1$)^{7}$

Genetz also studied the writings of the Swedish mystic Emanuel Swedenborg $(1688-1772)$ who was a scientist in physics, mechanics, and philosophy (Notebook 1). In his mid-life, Swedenborg went through a spiritual crisis and had revelations in which he encountered angels and Jesus, was taken

7 Original text in German, the translation has been done using Böhme s.d. to different parts of heaven and hell, and was taught the meaning of the Biblical texts (Galbreath 1986: 386; Williams-Hogan 2006: 1096-7).

According to Swedenborg, people had originally been able to read the Bible the same way the angels do and understand its true meaning, but eventually lost this ability. In order to understand the Bible, a modern person needs to learn the correspondences between things earthly and spiritual (Galbreath 1986: 386; Swedenborg 1940/1758, 2000/1784, 2009/1749-56; Williams-Hogan 2006: 1096-7). Genetz wrote in her notebook:

$$
\begin{aligned}
& \text { boy }=\text { innocence } \\
& \text { old man = wisdom } \\
& \text { maid = love for the truth } \\
& \ldots \\
& \text { mountain = heaven } \\
& \text { stars = knowledge } \\
& \ldots \\
& \text { sun = love } \\
& \text { moon = faith }(\text { Notebook } 1)^{8}
\end{aligned}
$$

Genetz's notes also cover the different parts of heaven and who resides in them, as well as Swedenborg's views on how the different stages of human understanding and language can be seen in biblical texts from different eras (Notebook 1).

From the Christian mystics, Genetz moved on to Theosophy, which she studied in Helena Blavatsky's book The Secret Doctrine (1888) (Notebook 1). Blavatsky (1831-91) was the key figure behind the Theosophical Society, which combined the views of old mythologies and religions with findings of the new sciences. According to Blavatsky, the 'deepest depths' of divinity were found in the ancient primitive 'wisdom

8 Original text in Swedish. 
religion, the Secret Doctrine, which had long been lost and forgotten. Only scattered pieces of it remained in the old sacred books and mythologies around the world (Blavatsky 1984a-b/1877). Genetz quoted Blavatsky on the correspondences of numbers and forms:

$\underline{6}=$ the physical nature, the 6 dimensions of all physical bodies, the 6 lines which compose their form ...

$\nabla$ the god of water (Narayana) Nara = water.

$\triangle$ Shiva $=$ fire

3,4 $=$ manly, female $=$ spirit, matter

| spiritual — material +

$(\text { Notebook } 1)^{9}$

Later, Genetz read another Theosophist, Mabel Collins's (1851-1927) book When the Sun Moves Northward (1912) (Notebook 1). The book gives instructions to spiritual disciples on how to attain rebirth. The journey begins with 'the Ceremony of the Desire for Birth. It lasts for four days and nights, and every day the student must meditate twice upon the words of a litany that Meri wrote to her notebook:

I I desire birth.

II I am ready to be burned and consumed; for that is what birth is.

III I am ready to be naked and unprotected, and to suffer from my nakedness; for that is what life is.

9 Original text in Swedish. The translation has been made using Blavatsky $1888 \mathrm{~b}$ : 5907.
IV I am ready to make the pilgrimage through matter in darkness and in fire, so that the circle of the uncreate shall become one with the circle of the create. $(\text { Notebook } 1)^{10}$

Afterwards follow more ceremonies and feasts with their own litanies and chants. Once they are over, the student is ready for the Feast of Birth: 'Now comes the opening of the golden gate, the lifting of the heavy iron bar that clasps and holds it' (Collins 1912: 6-15).

Genetz wrote down many of the litanies, but not all of them. This recurs in her notebooks: she finds instructions for methods which are claimed to lead to enlightenment or rebirth and writes down parts of them, but leaves out other parts or discontinues writing at some point (Notebooks 1-4). Four years later, in November 1929, she wrote: 'Gloomy is the November night, gloomy is the mind of one who lays in an iron coffin in the ground.... The Hero does not come, nor the King, who would open the locks, lift up the iron cover' (Notebook 2). ${ }^{11}$ These words are reminiscent of the wording of Collins's book. Genetz arguably never made it to the 'Ceremony of Birth', she never saw the 'Hall of Learning' furnished with 'clouds of glorious colour' and 'flaming jewels' flashing on the walls (Collins 1912: 10).

This, I think, is emblematic of Genetz's seeking. She read in her books about how a person would be able to develop spiritually, move forward, and reach the next levels of understanding. But the books were vague in their instructions: How do you know if you're doing the right things? How do

10 Original text in Finnish, the English translations are from Collins 1912.

11 Original text in Finnish. 
you know which stage you're at? How do you know if you've moved forward? And if you haven't, how do you know what you've done wrong?

At the end of 1925, a person entered Genetz's life who would have a big influence on her spiritual seeking and become a close friend: Aleksanteri Huttunen (18821942). Some members of the cultural elite held him in great esteem, and he has been described, for example, as 'Finland's greatest sage. Huttunen had made his living as a woodcutter and undertaking other physical labours, and, on the side, made 'psychoscopes' for those who were interested. Psychoscopes were reports in which a person's astrological chart was studied in order to give information about their previous lives, current situation, and future. At the beginning of the twentieth century, Huttunen found a new field of expertise: he started to interpret the hidden meanings of The Kalevala, an epic poem from the Karelia region (Anttonen 2009a: 187-8, 2009b: 199-201; Ryynänen 2019: 181-3).

The first English translation of The Kalevala had appeared in 1888 . In the same year Helena Blavatsky became acquainted with the poem and saw it to be new evidence of the universality of 'Archaic philosophy' (Blavatsky 1888a). In Finland, Theosophists started their own studies of The Kalevala in the 189os, including a widely-known Finnish Theosophist Pekka Ervast (1875-1934) who wrote books about The Kalevala and its esoteric meanings (Anttonen 2009a: 185; Ervast 1913, 1916).

Aleksanteri Huttunen had undoubtedly heard of the Theosophists' views and realised he could help people understand the hidden wisdom of The Kalevala. From 1921 at the latest he was regularly invited to Helsinki by the Finnish sculptor Eemil Halonen to speak about The Kalevala's esoteric meanings. Artists came to hear him speak, and in 1925 Genetz and Wargh joined them. Genetz was very impressed by Huttunen, who was skilful in combining Theosophical and new-age terminology with his own vulgar, provincial manner of speech, giving an impression of a spirited, profound, self-experienced understanding of the occult (Genetz, letters 21.7., 29.7., 10.8.1928, 14.1., 24.1.1929; Halonen, letter 5.4.1927; Hemdal 1953: 42; Notebook 1; Ryynänen 2019: 183-5; Toppelius-Nyberg, letter 14.11.1929).

Three years later Genetz wrote to her daughter:

Read The Kalevala. It is a book a wisdom, and one made by our ancient Finns whose ancestors have brought us Huttunen. How they look after their people. Huttunen was the high priest in a temple but wanted to bring Finland back a new (old) father, left his priesthood and got his son. We have wonderful ancestors. (Genetz, letter 5.8.1928)

Huttunen also offered Genetz his views on Tarot cards. Genetz was studying the Tarot through Oswald Wirth's book Le Tarot des imagiers du moyen-âge (1926; Tarot of the Magicians) which emphasised that the Tarot has a connection to the old Jewish mysticism, the Kabbalah (Wirth 1926).

It is thus quite logical that together with the Tarot, Genetz started to familiarise herself with Kabbalah. She read Erich Bischoff's two-volume book Die Elemente der Kabbalah (1913, 1915) where she learned, for example, that the 22 letters of the Hebrew alphabet can be divided into three groups: three 'mother letters', seven 'double letters', and twelve 'simple letters', which symbolise different things. The seven 
double letters, for instance, symbolise the opposites in the world because of their double nature - they have a hard and a soft pronunciation depending on their position in a word. Because of their number, they also symbolise all things that have seven parts or units, such as weekdays, planets, and the orifices of the head (Bischoff 1913: 68-77; Sepher Yetzirah 1887). Genetz wrote:

$$
\begin{aligned}
& \underline{B}=\text { rules wisdom Sunday. } \hbar \underline{\text { right }} \text { eye. } \\
& \underline{G}=\text { rules wealth. Monday. } 2 \underline{\text { left eye. }} \\
& \underline{\mathrm{D}}=\text { fertility Tuesday ot right ear } \\
& \underline{\mathrm{K}}=\text { life Wednesday } \odot \underline{\text { left ear }}
\end{aligned}
$$

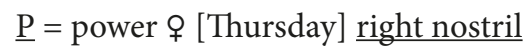

$$
\begin{aligned}
& \underline{\mathrm{R}}=\text { peace } \not{\zeta}[\text { Friday] left nostril } \\
& \text { Th = beauty D Sabbath mouth } \\
& \text { (Notebook 1) } 12
\end{aligned}
$$

The Kabbalists studied carefully the Old Testament to find its hidden meanings and wisdom. Genetz listed the descendants of Eleazar and Ithamar from 1 Chronicles and attached each name to an hour of day. In her notes there is also a list of the gatekeepers with explanations, such as: 'Johanan: merciful, blessed', as well as a list of the twelve sons of Israel whose names are combined with the twelve signs of the zodiac. The guardians of the king are also listed and combined with zodiac signs, body parts, plants, animals and so on (Notebook 1).

At the end of Genetz's first notebook, there are also notes on the writings of Paracelsus (1493-1541), an alchemist and

12 Original text in German. physician. Genetz wrote down recipes and instructions, for example a description of elixirs that can be derived from a body of a recently deceased person.

1) The watery and phlegmatic moisture forms a specific so potent that it heals and consolidates any wound in twenty-four hours.

2) From the fat, a most excellent balsam is produced, allaying the pains of gout, of contraction \& others of a like nature ...

3) If the watery moisture is separated from fatness from the bones and they are reduced ... to a white ash ... and if, lastly these three be again united ... there will be formed a wonderful ... specific, with which you will be able, without pain, to entirely cure any facture of the bones... (Notebook 1$)^{13}$

In Genetz's other notebooks, there are notes that are not dated but which, judging by the handwriting and style, might be from this period, around the year 1926 . They include notes on ancient Indian religious writings, the Vedas, together with excerpts from Dante Alighieri's Divine Comedy.

\section{Delineating her own theories}

In autumn 1926, Genetz was in Paris and wrote to her daughter Virma Ignatius (later Ramsay, 1910-66) that she often heard a voice telling her 'long stories and poems' (Genetz, letter 5.10.1928). One of these stories is to be found at the beginning of Genetz's second notebook. It is written in

13 Original text in Swedish. The translation has been done using Paracelsus 1894 . 
Finnish and starts with the words: 'Manu speaks, I listen.' According to Hinduism, the first Manu had been the progenitor and lawgiver of the human race. Later every era of 4,320,000 years has had its own Manu. Theosophists adopted the idea and taught that each root race of mankind had had their own leader, Manu (Blavatsky 1888b: 307-13; Daniélou 1991: 326-7).

Genetz's text continues:

In the heart of the Earth, in the darkness, where no beam of light plays, live the world's children. ... [E]ternal sufferings carve grooves on their soft flesh. Their minds are gloomy backwoods, no grass grows there, no tree.

(Notebook 2)

Genetz calls the world's children Manu's children. All they do is evil: desire more riches, take away what someone else has, take women by force. At the same time, they are full of anguish. There is no reason for living, no hope, just sin and pleasure. But then Manu starts to regret the way they've lived. He begs: 'Our Ukko, ${ }^{14}$ help, give me strength, give me sense, give me the ardour of your spirit, love's great fire.' And a great flame is born, the children of darkness see a miracle, a light lit by Manu.

At the same time another group of people have been living in the daylight: the children of Josa. They thank the Lord for not being like those wretched denizens of the underworld. They are blessed, looked after by Josa, who 'lived once, suffered, rose up from grave, bought this people with his blood'. The children of Josa have peace in their hearts, but they keep a safe distance from Manu's children and their faith: 'We

14 Ukko is the supreme god in the old Finnish mythology. don't want to see it or hear about it, it might chase away our good peace, our heaven, our belief.' It is evident that of the two, Genetz has higher regard for Manu's children and their fearless seeking. She writes:
Darkness creates light, anguish cre- ates peace, sin penitence, night creates a day, evening a morning, experience creates wisdom. Remember Manu's child, when you suffer, you suffer yourself happiness, through suffer- ing you think yourself understanding. (Notebook 2)

This story is, in my opinion, the key to Genetz's seeking. She thinks that religions offer ready-made solutions. Those who accept their truths will have it easier and live in peace, but they will always have to protect their beliefs from outer influences. Any dissonance from other religions or beliefs might disturb their peace. Genetz herself would rather go through anguish and hardships to find a more lasting truth.

Genetz's second notebook is very different from the first one. She writes down hardly any excerpts from books anymore; now she makes notes on her own thoughts, ideas, and feelings. Even when she does study the theories of others, she combines them with her own thinking. Around 1929, Genetz made notes on the writings attributed to Hermes Trismegistus, a mythic, god-like personality, seen to be great in wisdom and knowledge (van den Broek 2006b: 474-7). Genetz's notes are about intelligence:

The soul's sin is ignorance.

Knowledge is the end of science.

... Intelligence purified and released from its shell, divine by nature, will take a Fire body. (Notebook 2) 
Genetz uses the idea of intelligence in developing a view on painting:

In order to paint, one does not need disposition, only Intelligence. Painting is an art that not yet even painters seem to understand. It is the 'music' of colours and does not need other substances in order to be a painting than forms and colours. To represent something is for literature. [Painting] ... expresses feelings, thoughts and cosmic truths with its sound of colours and rhythm of colour and lines. No skilfulness is asked to perform these, only Intelligence, which understands and knows how to present what it understands. (Notebook 2)

\section{The other half}

In her second notebook, Genetz wrote a poem about how to find one's true love.

Sit quietly, do not seek! Listen in the night! Your own voice will talk to you inside your soul. My love, it is me, the one you're looking for. Your own, yourself. At last, after thousands of years, you sought from the only place where you will find your spouse. Here I am, and you and I will be one!

This note is the first mention of Genetz trying to find someone who would complete her, be her spiritual spouse. In a year or two, this longing would transform itself into a search for the 'other half', which would then become the main goal of Genetz's spiritual seeking (Notebooks 2-4; Ryynänen 2019: 204ff.). In 1928, Genetz wrote to her daughter about what she had read in the Kabbalistic book the Zohar about the two sexes: originally Elohim had created a whole human comprising the two sexes, but eventually they were split apart, which also made them lose their human quality and become animals. At the wedding in Cana they would, however, be able to reunite and become whole - and human - again. Genetz wrote:
As long as one seeks for the other half from the outside, one finds only a false image. Inside, true image $=$ The other half; when that has been found, it can also be found outside. (Genetz, letter $21.7 .1928)^{15}$

In December 1928, Genetz wrote to her daughter about Claudius Grillet's book Victor Hugo spirite (1914). According to Genetz, Victor Hugo had found his 'other half' in a Spiritualist séance:

Hugo was united with his other half and was 'killed' one night. Then he awoke from 'death.' His handwriting changed, he shone. He woke up. Everywhere he could see a spirit. ... He became alive. Development is miraculous. (Genetz, letter 8.12.1928)16

It seems Genetz started hoping the same might happen to her. She returned to Finland in July 1929, and in November 1930 the first mention of a Spiritualist séance can be found in her notebooks. From there on, the séances took place approximately once a month. In the second of these, Genetz asked the spirit if he was her other half. The spirit answered 'Yes'. However, in the months to come, it would constantly change its mind (Notebook 2).

The notes of the first séance begin: 'Psychograph in Nov. 1930 with S. as a medium.' The word 'psychograph' suggests that a system has been used where the

15 Original text in Finnish.

16 Original text in Finnish. 


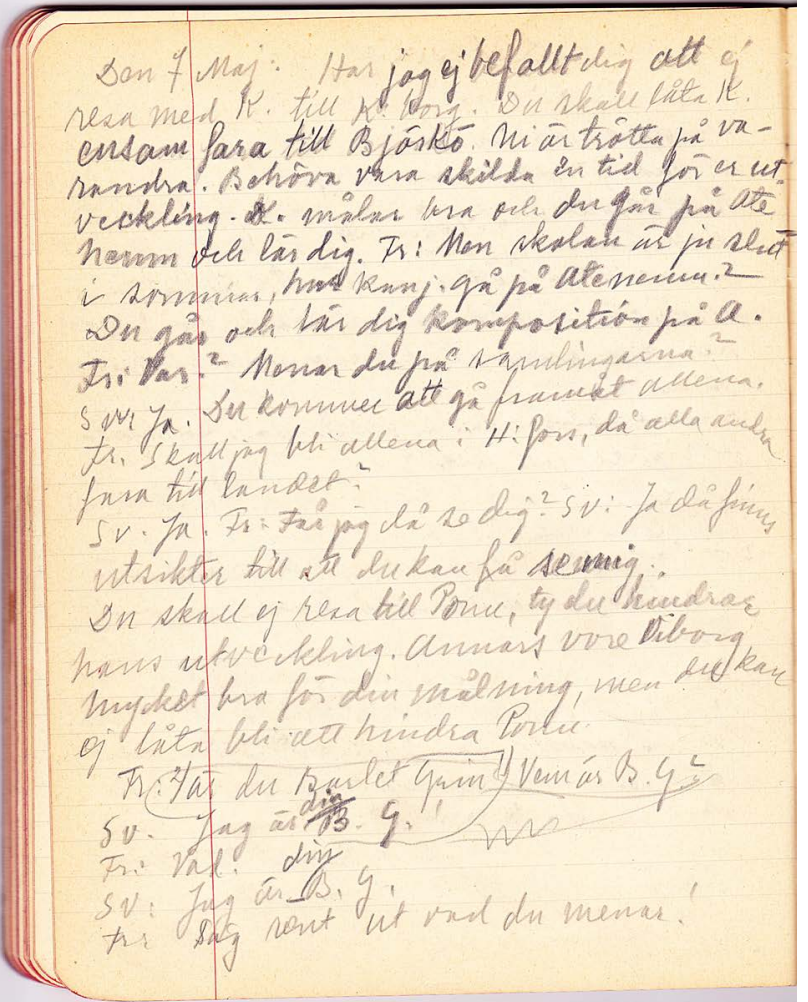

Page from Notebook 2. Private collection.

answers to questions are obtained by selecting letters and in that way forming words. The séance seems to have been conducted in Swedish, since the notes are in Swedish even though the notebook has otherwise been written in Finnish (Notebook 2).

In the séances Genetz also wanted to know if her soul was ready, and if she could soon be 'killed' and 'reborn'. In addition, she asked about her painting: if her work would be accepted into exhibitions, and what the critics would say about it. The spirit offered instructions on her art as well. In September 1931, she was told: 'You will paint according to the old drawings that you're interested in!' In October 1931: 'You need to paint less formally, independently', and in August 1932: 'You must learn composition and technique, study the old masters' (Notebook 2). ${ }^{17}$
Problems in marital life were discussed, together with the situations of friends and acquaintances: their spiritual stage, if they had a soul or not, and if they could be trusted or not. The spirit's views were usually suspicious and grim. For example, on April 1931 Genetz was told:
You have been Huttunen's disciple. He wants to keep you in his realm. Does not know that you have become Living, ... [he] would have taken your will $\ldots$ and you would have become a phantom. (Notebook 2) ${ }^{18}$

In addition to the Zohar, Genetz read about human gender identity from Dmitry Merezhkovsky's books, such as Jumalien kuolema (1923-4; The Death of the Gods) and Die Geheimnisse des Westens. AtlantisEuropa (1929; Atlantis/Europe, the Secret of the West). Merezhkovsky saw a perfect human to be androgynous, and Genetz welcomed the idea. In her notebook, she drew a cross; next to the vertical line she wrote 'man', and next to the horizontal line 'woman. ${ }^{19}$ On the right side of the picture she wrote: 'In hoc signo vincis!' ('In this sign thou shalt conquer!'). Genetz wasn't at ease with her female sex; according to her friend Dag Hemdal she wanted to be a man (Hemdal, letter 1.2.1940; Notebook 2; Ryynänen 2019: 205; Tirranen s.d.).

\section{Darkening tones}

After 1933, Genetz practically disappears for six years. Only few separate mentions of her life can be found in friends' and relatives' letters and in the diaries of Genetz's acquaintance Axel Ringström (1858-1945)

17 Original text in Swedish.

18 Original text in Swedish.

19 Original text in Swedish. 
who was a well-known medium and healer (Ringström 1924-39).

This was a difficult time for Genetz. Her marriage was in ruins, and she and Wargh were both suffering from what would nowadays be probably called depression and anxiety. In November 1934, Ringström wrote in his diary:

At 10.30 pm Mrs. Meri Nyman phoned saying that reliable information had just come from the spiritual realm that she will be killed; first some creatures will come and rip her body into pieces, then the animals will come and eat the rest of the body. She said that the day before yesterday she had got a salon initiation and, because of this, they now want to take her life from opposite sides. (Ringström 1924-39) 20

In 1935, Wargh had a child with Kerttu Vuori. Vuori and her husband, the artist Ilmari Vuori, were close friends to Wargh and Genetz. It is possible that having the child had been agreed among the couples, but nevertheless it led to a secret relationship between Wargh and Kerttu Vuori (Airi Salosmaa, personal communication 4.5.2019). In 1937, their relationship became public. Wargh was anxious about how people would react and became more and more depressed. He threatened to shoot both Genetz and himself and finally committed suicide in March 1937 (Genetz, letter 29.3.1937; Ryynänen 2019: 237, 250-64).

It is possible that Genetz destroyed the notebooks and diaries from these sombre years. Her notes reappear in a systematic form only in August 1939. She no longer forms theories - now she describes her spiritual experiences, visions and dreams,

20 Original text in Swedish.

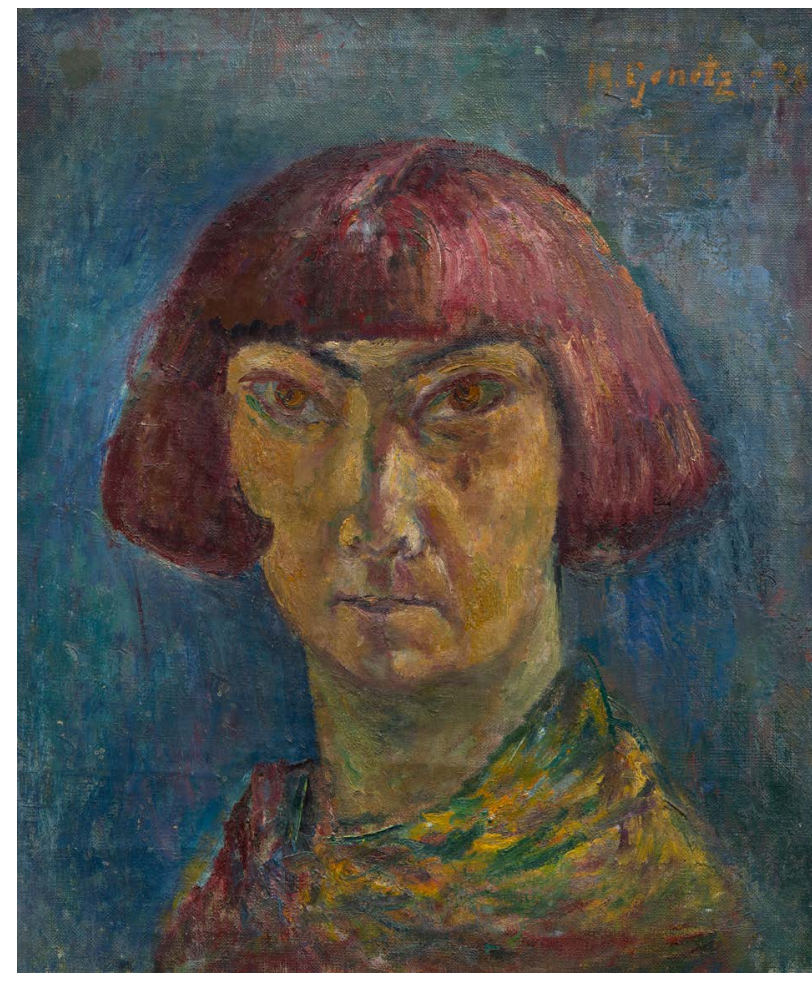

Meri Genetz, Self portrait, 1938, oil on canvas, 56.0 x $46.7 \mathrm{~cm}$. Signe and Ane Gyllenberg Foundation/Villa Gyllenberg. Photo: Matias Uusikylä.

together with the discussions on the occult she's had with her friends. The spiritual experiences often take place at night-time (Notebook 3).

A sword went (better, was jammed), the sword of the truth, through my heart and that way the heart's contents were studied. There were, for example, my cosmetics that belong to the false ones. A white mask was pressed on my face and at length was studied to see if I could be accepted for a disciple. $(\text { Notebook } 3)^{21}$

Some of her visions have a distressing tone.

21 Original text in Finnish. 
The whole hell opened, fire and flames that threatened to 'drown me'. Begged for help from all Christ's servants, from Tiboth $^{22}$, from all the white Brothers and lastly from the great temple with all the fortunate who have gone there, and finally help came with great force. (Notebook 3$)^{23}$

Spiritualist séances still took place, but now they happened among small groups of intimate friends. The notes from the séances no longer follow the question-and-answer format: instead they are longer narrations, that supposedly have been delivered and dictated without actual devices such as a psychograph (Notebook 3).

\section{The Tibetan}

In February 1940, one of Genetz's friends, Mrs Lipponen, told Genetz about a dream she had had about a castle. On the third floor there was a big, black sign with the name 'Meri Genetz' on it. On the fourth floor it said: 'A trip to Tibet.' On the fifth, a light was lit, and it said: 'Meri Genetz's road ends' (Notebook 3).

Genetz had been keenly interested in Tibet, from 1938 at the latest. She was certain that someone from Tibet would come and take her there with him. In her most cherished vision she stood on a mountain top in Tibet with her other, higher half standing next to her (Notebooks 3-4; Ryynänen 2019: 278; Tirranen s.d.).

In 1942, Lipponen prophesied that the Tibetan would come on July 20. According to ToiToi ${ }^{24}$, he would arrive August 23 or

22 Possibly Genetz's spirit guide.

23 Original text in Finnish.

24 Probably a nickname of the daughter-inlaw of Genetz's artist friend, Uuno Alanko.

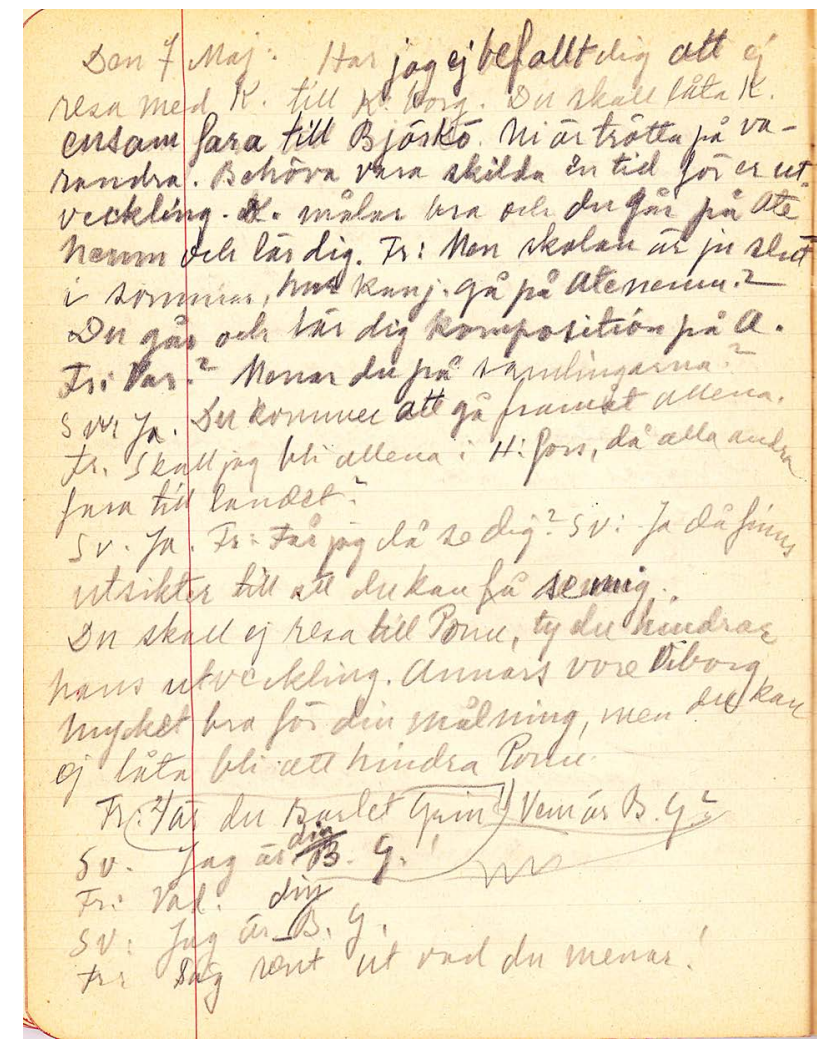

Page from Notebook 4. Private collection.

24. After that, he was supposed to come in September, then in November or December, then on the first Sunday after New Year. In January 1943, he had still not appeared, but Genetz was told he would make it before February 1943 (Notebook 4).

Genetz's friends also frequently brought messages concerning her son, Urma Ignatius, who had died on the battlefront early in the morning of the first day of 1940. According to the information Genetz got from her friends in this way, Ignatius was always a great sage or held a highly respectable position in the spiritual world (Notebooks 3-4).

A third popular topic was the war. In July 1942, the spirits told ToiToi that peace would come 'before the snow' The Mongolians would drive in a wedge near Moscow, and the European armies 
would not be defeated. A later message said that there would be an armistice before Christmas, and yet another that the war would be over by September, when Germany would defeat Russia (Notebooks 3-4).

\section{Restless seeking}

Genetz's last notebooks give the impression she had become less patient in her studies of the occult. She does not concentrate at length on different books or theories anymore but seeks information and experiences through more direct channels. She also changes constantly between different methods of acquiring information or seeking spiritual development (Notebooks 3-4).

The fourth notebook begins with a long section of text that seems to have been produced by means of automatic writing. Automatic writing is produced without planning or thinking, as passively as possible, speedily and without stopping. The esotericists used it in order to receive messages from the spiritual world (LeskeläKärki 2006: 277-80). Genetz's text is written in Finnish, and it begins:

Heaven's spirit the Lord is. This human. If I step, has spirit's Lord always been, sits in the name of the Father, the Mother, to the Son in the matter of the world, the new spirit of the Big Dipper. Truth always the Big Dipper. The highest in the matter below. No-one who sees the human believes that the spirit of the Big Dipper, the Lord of the Heavens. (Notebook 4) 25

For twenty pages, the text continues in similar manner. After that, Genetz starts to write in tongues: 'Lontin äklä, tikla, matla, kaute kladla, Lampan di, emla, ikla vailla, kaiken kaija, klotats, kanmkale, sanklan.'

After a few paragraphs, she returns to Finnish. Altogether, the text extends over forty pages (Notebook 4).

During autumn 1942, Genetz tried out different meditation methods. In October, she wrote: 'Started Om mani padme hum' referring to the widely used Buddhist and Hindu mantra. In November she wrote down instructions for a contemplation method developed by Ignatius Loyola. The programme lasts for four weeks, and the practitioner is supposed to meditate five times a day (St. Ignatius of Loyola 1909).

At the same time, she was also reading Rudolf Steiner's instructions for meditation from Huru uppnår man kunskap om de högre världarna (1932; Initiation and Its Results) (Notebook 4). Steiner was the founder of the esoteric Anthroposophy movement (Leijenhorst 2006: 1084, 10901). In his book, he gave advice on how to make the astral body more organised and achieve clairvoyance by training the chakras (Steiner 1909: 11-19).

Genetz's last dated notes are from 25 March 1943. She has had a séance with her friend Lahja Pelttari who functioned as a medium. Genetz was told: 'You will be in contact with Ponu tonight' - Ponu was the nickname of Genetz's deceased son, Urma Ignatius (Notebook 4). A week later Genetz was found unconscious in her apartment. Gas was flowing from the two burners of her small stove. She was taken to a hospital where she died 3 April without gaining consciousness (Ryynänen 2019: 305-7).

On the cover pages of Genetz's last notebook, there are Tibetan words written in both alphabets and translated into Swedish. Genetz was getting ready to go to Tibet. 


\section{Afterword}

Meri Genetz's spiritual seeking began in 1925 from becoming acquainted with the occult and esoteric literature of her time: Gnosticism, Christian esotericism, Theosophy, and Kabbalah. Later her seeking became more personal, as she started writing down her own feelings, visions, and dreams. With time, Genetz's seeking became increasingly sensational, impatient, and restless. The last notebooks show Genetz trying out different ways of approaching the spiritual realm, practically simultaneously.

Around 1927, Genetz became especially interested in the idea of the 'other half'. The human would have originally comprised both a male and a female part, but later had been split to two halves. Genetz's greatest hope became to find her other half and thus become whole, alive. It was also one of the first things she enquired about when she began participating in Spiritualist séances in 1930.

By 1939, communication with the spiritual world started to take place through direct channels: dreams, visions, and messages delivered through Genetz's friends. The topics repeated themselves: Where is Genetz's other half, and will she meet him soon? Who to trust, who not? How is Genetz's son doing in the afterlife? And above all: When will the Tibetan come to take Genetz away?

In the early years of her seekership, Genetz wrote a story about Manu's children. They would not settle for accepting a ready-made religion, or the peace that would supposedly come with one. In Genetz's opinion, a true faith and a lasting peace could only be obtained through hard work and relentless seeking. She held on to this conviction all her life; but in the end she was still without peace, and still seeking.
Sanna Ryynänen is an editor, journalist, and researcher who has written a book on Meri Genetz. It is the only comprehensive study made of Genetz's life so far. At the moment, Ryynänen is working on her doctoral dissertation, in which she studies the representation of immigrants in Finnish journalist texts in two different eras. Her monograph Meri Genetz - levoton sielu was published in 2019.

\section{References}

Letters

Genetz, Meri 20.2.1917 to Teodor Schalin. Åbo Akademi University's archive, manuscripts, Teodor Schalin's collection.

Genetz Meri 21.7., 29.7., 5.8., 5.10., 8.12.1928; 14.1., 24.1.1929 to Virma Ignatius, in Helena Hernberg's possession.

Genetz Meri 10.8.1928 to Virma and Urma Ignatius, in Helena Hernberg's possession.

Genetz, Meri 29.3.1937 to Aleksanteri Huttunen. Finnish National Gallery's Archive, Meri Genetz's atelier's collection.

Genetz, Meri 1903-43. Letters and cards written to and received from friends and relatives. In possession of relatives, and in the National Archives of Finland, Åbo Akademi University's archive and Finnish National Gallery's Archive. Detailed information in Ryynänen (2019).

Halonen, Kalle 5.4.1927 to Eemil Halonen. Archives of the Finnish Literature Society, Alli and Emil Halonen's collection.

Hemdal, Dag 1.2.1940 to Meri Genetz. Finnish National Gallery's Archive, Meri Genetz's atelier's collection.

Toppelius-Nyberg, Maria 14.11.1929 to Teodor Schalin. Åbo Akademi University's archive, manuscripts, Teodor Schalin's collection.

\section{Other sources}

Ahlman, Daniela. 1980. Radio programme on Meri Genetz's exhibition. Sommarkanalen. [Detailed information on the program or channel cannot be found.] 
Calendar. 1932. Genetz's calendar for year 1932. Finnish National Gallery's Archive, Meri Genetz's atelier's collection.

Notebooks 1, 2 and 4. Meri Genetz's notebooks. In possession of Katarina Michelsson.

Notebook 3. Meri Genetz's notebook. Finnish National Gallery's archive, Meri Genetz's atelier's collection.

Ringström, Axel. 1924-39. Diaries from years 1924-39. The National Archives of Finland, Axel Ringström's collection.

Small notebook. Genetz's small notebook, likely from the beginning of 1930s. Finnish National Gallery's Archive, Meri Genetz's atelier's collection.

Sonck, Carl Eric. 1980. Speech in the opening of Meri Genetz's retrospective exhibition. Bäcksbackas konstsalongen art gallery, 31.8.1980.

Tirranen, Hertta. s.d. Notes for the article on Meri Genetz and Carl Nyman Wargh in Tirranen (1950). The University of Helsinki, the archive of Art History, Hertta Tirranen collection.

\section{Literature}

André Lhote ja Suomi, Sara Hildénin taidemuseon julkaisuja, 9 (Tampere: Sara Hildénin taidemuseo, 1982).

Anttonen, Erkki. 2009a. 'Kalevalan uskonnollisia ja teosofisia tulkintoja 1900-luvun kuvataiteessa, in Kalevala kuvissa. 160 vuotta Kalevalan innoittamaa suomalaista taidetta, ed. Riitta Ojanperä (Helsinki: Ateneumin taidemuseo), 185-97.

_- 2009b. 'Selvännäkijä Aleksanteri Huttunen', in Kalevala kuvissa. 160 vuotta Kalevalan innoittamaa suomalaista taidetta, ed. Riitta Ojanperä (Helsinki: Ateneumin taidemuseo), 199-201.

Behmen, Jacob. s.d. The Four Complexions: Or, a Treatise of Consolatory Instruction Against the Time of Temptation for a Sad and Assaulted Heart (London: J. Scott), <https:// play.google.com/books/reader?id=huZbAAAAQAAJ \&hl=fi\&pg=GBS.PR $1>$ (accessed 7.9.2020).

Bischoff, Erich. 1913. Die Elemente der Kabbalah. Erste Teil: Theoretische Kabbalah. Geheime Wissenschaften (Berlin: Hermann Barsdorf Verlag).

Blavatsky, Helena. 1984a. Hunnuton Isis. I osa:
Tiede [orig. Isis Unveiled, 1877], trans. Sirkka Virolainen (Helsinki: Ruusu-Ristin kirjallisuusseura).

——1984b. Hunnuton Isis. II osa: Tiede [orig. Isis Unveiled, 1877], trans. Sirkka Virolainen, Timo Nurminen and Heli Makkonen (Helsinki: Ruusu-Ristin kirjallisuusseura).

- -1888a. 'The national epic of Finland', Lucifer, 3(14): 149-52.

- $1888 \mathrm{~b}$. The Secret Doctrine: The Synthesis of Science, Religion, and Philosophy, vol. 2, part 2, <https://www.sacred-texts.com/the/ sd/index.htm\#pt23> (accessed 2.1.2020).

- -1909. 'Suomen kansalliseepos', Tietäjä, 3: 77-81.

Böhme, Jakob. 2009/1656. Of True Repentance, of Regeneration, of True Resignation, of the Super-Sensual Life [orig. 1656], $<$ https://inthecompanyofmystics.blogspot.com/2009/10/boehme-of-true-repentence-of.html $>$ (accessed 27.1.2020).

- - s.d. Aurora the Day-Spring, or Dawning of the Day in the East or Morning-Redness in the Rising of the Sun, <http://jacobboehmeonline.com/yahoo_site_admin/assets/docs/ AURORAjbo.77133023.pdf $>$ (accessed 8.1.2020).

Broek, Roelof van den. 2006a. 'Gnosticism I: Gnostic religion', in Dictionary of Gnosis \& Western Esotericism, ed. Wouter J. Hanegraaff (Leiden: Brill), 403-16.

- - 2006b. 'Hermes Trismegistus I: Antiquity', in Dictionary of Gnosis \& Western Esotericism, ed. Wouter J. Hanegraaff (Leiden: Brill), 474-8.

Collins, Mabel. 1912. When the Sun Moves Northward: The Way of Initiation (London: Theosophical Publishing Society), $<$ https://www.philaletheians.co.uk/studynotes/higher-ethics-and-devotion/whenthe-sun-moves-northward-by-collins.pdf $>$ (accessed 3.1.2020).

Holm, Dan, and Carl Wargh. 1995. Carl Nyman Wargh (Vaasa: Pohjanmaan museo).

Daniélou, Alain. 1991. The Myths and Gods of India (Rochester: Inner Traditions International).

Ervast, Pekka. 1913. Suomen kansallishaltia (Helsinki: Teosofinen kirjakauppa ja kustannusliike).

- -1916. Kalevalan avain (Helsinki: Teosofinen kirjakauppa ja kustannusliike). 
Galbreath, Robert. 1986. 'A glossary of spiritual and related terms', in The Spiritual in Art: Abstract Painting 1890-1985, ed. Maurice Tuchman (Los Angeles County Museum of Art), 367-91.

Hemdal, Dag. 1953. 'Lodare i huvudstan', Lucifer, 1953: 40-2.

Irenaeus, s.d. 'Against heresies', in Ante-Nicene Fathers, vol. I, ed. Alexander Roberts (The Gnostic Society Library), <http://www. gnosis.org/library/advh1.htm> (accessed 28.1.2020.

King James Bible Online, <https://www. kingjamesbibleonline.org/> (accessed 27.1.2020).

Klinge, Matti. 2006. Iisalmen ruhtinaskunta. Modernin projekti sukuverkostojen periferiassa (Helsinki: SKS).

Kokkinen, Nina. 2019a. Totuudenetsijät. Esoteerinen henkisyys Akseli Gallen-Kallelan, Pekka Halosen ja Hugo Simbergin taiteessa (Tampere: Vastapaino).

- 2019b. Totuudenetsijät. Vuosisadanvaihteen okkulttuuri ja moderni henkisyys Akseli Gallen-Kallelan, Pekka Halosen ja Hugo Simbergin taiteessa, $\mathrm{PhD}$ dissertation, University of Turku.

Konttinen, Riitta. 2010. Modernistipareja (Helsinki: Otava).

Leijenhorst, Cees. 2006. 'Steiner, Rudolf', in Dictionary of Gnosis \& Western Esotericism, ed. Wouter J. Hanegraaff (Leiden: Brill), 1084-91.

Leskelä-Kärki, Maarit, 2006. Kirjoittaen maailmassa. Krohnin sisaret ja kirjallinen elämä (Helsinki: SKS).

Maeterlinck, Maurice. 1905. The Treasure of the Humble (Edinburgh: Ballantyne, Hanson \& Co).

Meyrink, Gustav. 1916. Das grüne Gesicht (Leipzig: Kurt Wolff Verlag).

Paracelsus. 1894. The Hermetic and Alchemical Writings of Aureolus Philippus Theophrastus Bombast of Hohenheim, called Paracelsus the Great, edited by Arthur Edward Waite (London: James Elliot and Co).

Ryynänen, Sanna. 2019. Meri Genetz - levoton sielu (Helsinki: Avain).

Sepher Yetzirah or the Book of Creation, trans.

W. W. Westcott (1887), <https://www. sacred-texts.com/jud/yetzirah.htm> (accessed 9.1.2020).
Sonck, Carl Eric. 1995. Ihotautilääkäri muistelee (Klaukkala: Recallmed).

Steiner, Rudolf. 1909. Initiation and Its Results (New York, NY: Macoy Publishing and Masonic Supply Co.).

St. Ignatius of Loyola. 1909. The Spiritual Exercises of St. Ignatius of Loyola, trans. Elder Mullan, < https://www.sacred-texts.com/ $\mathrm{chr} / \mathrm{seil} / \mathrm{seilo7} \cdot \mathrm{htm}>$ (accessed 3.2.2020).

Swedenborg, Emanuel. 1940. Taivas, sen ihmeet ja helvetti [orig. De Caelo et Ejus Mirabilibus et de Inferno. Ex Auditis et Visis, 1758], trans. P. A. Koskenhovi (Hyvinkää: Suomentaja).

- 2000. Clavis Hieroglyphica. Hieroglyfinen avain ja muita filosofisia tekstejä [orig. Clavis hieroglyphica arcanorum naturalium \& spiritualium, 1784], trans. Jyrki Siukonen (Helsinki: Gaudeamus).

--2009. Arcana Coelestia: The Heavenly Arcana Contained in the Holy Scripture or Word of the Lord Unfolded, Beginning with the Book of Genesis, vol. 1 [orig. texts published in 1749-56], trans. John Clowes, $<$ https://swedenborg.com/wp-content/ uploads/2013/03/swedenborg_foundation_arcana_coelestia_01.pdf> (accessed 2.1.2020).

Tirranen, Hertta. 1950. Suomen taiteilijoita Juho Rissasesta Jussi Mäntyseen (Porvoo: WSOY), 427-41.

Toppelius, Gustaf. 1891. Är en kungsväg till vetande möjlig? En fråga, besvarad af erfarenheten $i$ våra dagar (Helsingfors: C. W. Edlunds förlag).

Williams-Hogan, Jane. 2006. 'Swedenborg, Emanuel', in Dictionary of Gnosis \& Western Esotericism, ed. Wouter J. Hanegraaff (Leiden: Brill), 1096-1105.

Wirth, Oswald. 1926. Le Tarot des imagiers du Moyen Âge (Paris: Tchou). 